\title{
Anticancer 4: Anticancer and DNA cleavage studies of some new Schiff base titanium (IV) complexes
}

\author{
Ali Gumaan El-Shekeil a,*, Abeer Omer Abubakr a, \\ Sama Abdalla Al-Aghbari ${ }^{a}$ and Mogahid Yahya Nassar ${ }^{b}$ \\ a Chemistry Department, Faculty of Science, Sana'a University, Sana'a, 33000, Yemen \\ b Pathology Department, Faculty of Medicine, University of Science and Technology, Sana'a, 33000, Yemen \\ *Corresponding author at: Chemistry Department, Faculty of Science, Sana'a University, Sana'a, 33000, Yemen. \\ Tel.: +967.7.33215234. Fax: +967.1.464484. E-mail address: shekeil2000@yahoo.com (A. El-Shekeil).
}

\section{ARTICLE INFORMATION}

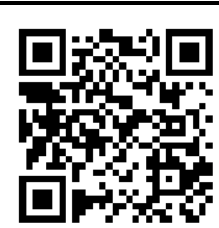

DOI: $10.5155 /$ eurjchem.5.3.410-414.996

Received: 07 December 2013

Received in revised form: 18 January 2014

Accepted: 27 February 2014

Online: 30 September 2014

\section{KEYWORDS}

\section{Titanium}

DNA studies

Sulfamethoxazole

Anti-cancer activity

Schiff base complexes

3,4-Dimethoxybenzaldehyde

\section{Introduction}

Coordination compounds of biologically active ligands have received much attention [1-3]. Chelation causes drastic change in the biological properties of the ligands and also the metal moiety. A number of Schiff-base complexes [4-7] have been tested for biological activities and showed antibacterial [8-11], antifungal [10-12], anticancer [13-14] and herbicidal [15] activities. It is known that the existence of metal ions bonded to biologically active compounds may enhance their activities [1618]. Following the discovery of cis-platin and its anticancer activity, there has been a growing interest in investigations of other platinum-based compounds [19] as well as non-platinum systems, and evaluating their potential value as anticancer reagents [20-23].

Among other metals that have been studied, two families of titanium complexes, titanocene dichloride and derivatives, and budotitane and analogs, showed interesting activities towards a number of tumor cell types, including those resistant to cisplatin, and with reduced toxicity [24-30].

A variety of possible Schiff base metal complexes with a wide choice of ligands, and coordination environments, have prompted us to undertake research in this area [31-32]. Metallocene dichlorides $\left(\mathrm{Cp}_{2} \mathrm{MCl}_{2}\right)$ with $\mathrm{M}=\mathrm{Ti}, \mathrm{V}, \mathrm{Nb}$ and $\mathrm{Mo}$ show remarkable antitumor activity [33-34]. We are interested in studying titanium complexes in more detail, and investigating additional non-Cp-based systems.

In continuation of our previous studies [35] in this work, Schiff base ligands were prepared by condensation of an equimolar mixture of sulfamethoxazole and the aldehyde (3,4,5-trimethoxybenzaldehyde or 3,4-dimethoxybenzaldehyde). The ligands were reacted with titanium(IV) chloride to get Schiff-base complexes. Characterization, electronic properties, DNA cleavage and anticancer effects were reported.

\section{Experimental}

\subsection{Chemicals}

Sulfamethoxazole was purchased from Virchow Drugs Ltd., India. Titanium tetrachloride, 3,4,5-trimethoxybenzaldehyde and 3,4-dimethoxybenzaldehyde were obtained commercially from Aldrich Chemicals. The solvents: dry absolute ethanol and diethyl ether were reagent grade and were used as received.

\subsection{Instrumentation}

The melting points were measured on an electrothermal melting point apparatus and were not corrected. 


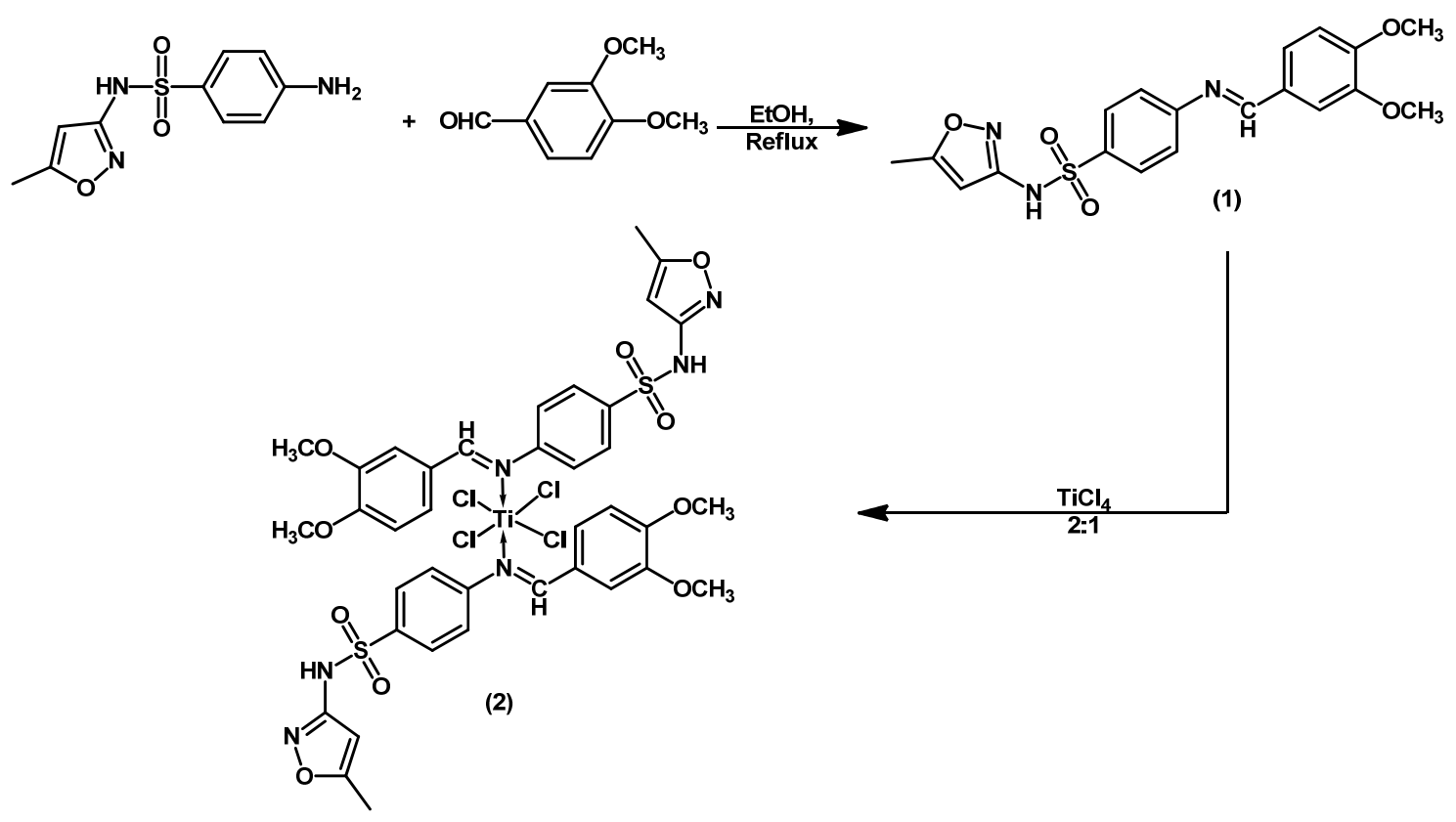

Scheme 1

Fourier-transform infrared spectra were recorded using the $\mathrm{KBr}$ disc technique on a JASCO 410 FTIR spectrophotometer. Elemental (CHN) analysis was performed using an Exeter CE-440 elemental analyzer. UV-visible absorption spectra were measured in DMF using a Pye-Unicam 8800a UV-visible automatic scanning spectrophotometer. Molar conductivity was measured on a systronic conductivity bridge with a dip-type cell, using $1 \times 10^{-3} \mathrm{M}$ solution of complexes in DMF. ${ }^{1} \mathrm{H}$ NMR spectra of the ligands and their complexes were recorded on a Varian Gemini-200 spectrometer using DMSO- $d_{6}$ as solvent and TMS as internal reference. Anticancer activity was evaluated at the International Center for Chemical Sciences and Dr. Panjwani Center for Molecular Medicine and Drug Research, University of Karachi, Pakistan.

\subsection{Synthesis of Schiff base ligands}

Schiff base compounds were prepared by condensation of an equimolar mixture $(0.01 \mathrm{~mol})$ of sulfamethoxazole and the aldehyde (0.01 mol) 3,4,5-trimethoxybenzaldehyde or 0.01 mol) 3,4-dimethoxybenzaldehyde, respectively, in ethanol (25 $\mathrm{mL}$ ). The mixture was refluxed for 24 hours under nitrogen atmosphere. Schiff base compounds were isolated and purified by diethyl ether after reduction of solvent volume by evaporation in a rotary evaporator (Scheme 1 and 2$)$.

4-(3,4-Dimethoxybenzylideneamino)-N-(5-methylisoxazol-3yl)benzene sulfonamide (1): Color: Orange. Yield: 92\%. M.p.: 204-205 ${ }^{\circ} \mathrm{C}$. FT-IR (KBr, v, cm${ }^{-1}$ ): 3432 (NH), 1654 (C=N), 1619 $(\mathrm{C}=\mathrm{N}), 1576(\mathrm{C}=\mathrm{C}) .{ }^{1} \mathrm{H}$ NMR $\left(200 \mathrm{MHz}, \mathrm{DMSO}-d_{6}, \delta, \mathrm{ppm}\right): 10.99$ $\left(\mathrm{s}, 1 \mathrm{H}, \mathrm{D}_{2} \mathrm{O}\right.$ exchangeable $\left.\mathrm{NH}\right), 9.79(\mathrm{~s}, 1 \mathrm{H}, \mathrm{CH}$, azomethine) 6.59-7.47 (m, 7H, Ar-H), $6.06(\mathrm{~s}, 1 \mathrm{H}$, isoxazole), $3.72(\mathrm{~s}, 3 \mathrm{H}$ $\left.\mathrm{OCH}_{3}\right), 3.84\left(\mathrm{~s}, 3 \mathrm{H}, \mathrm{OCH}_{3}\right), 2.29\left(\mathrm{~s}, 3 \mathrm{H}, \mathrm{CH}_{3}\right.$ methyl isoxazole $)$ Anal. calcd. for $\mathrm{C}_{19} \mathrm{H}_{19} \mathrm{O}_{5} \mathrm{~N}_{3} \mathrm{~S}$ : C, 56.85; H, 4.77; N, 10.47. Found: C, 56.08; H, 3.90; N, 9.24\%. UV/Vis (DMF, $\lambda_{\max }, \mathrm{nm}$ ) : 215,292 , 343.

$N$-(5-Methylisoxazol-3-yl)-4-(3,4,5-trimethoxybenzylidene amino)benzene sulfonamide (3): Color: Yellow. Yield: 75\%. M.p.: 220-223 ${ }^{\circ} \mathrm{C}$. FT-IR (KBr, v, cm-1): $3430(\mathrm{NH}), 1656(\mathrm{C}=\mathrm{N}), 1623$ ( $\mathrm{C}=\mathrm{N}$ ring), $1580(\mathrm{C}=\mathrm{C}) .{ }^{1} \mathrm{H}$ NMR $\left(200 \mathrm{MHz}, \mathrm{DMSO}-d_{6}, \delta, \mathrm{ppm}\right)$ : $10.95\left(\mathrm{~S}, 1 \mathrm{H}, \mathrm{D}_{2} \mathrm{O}\right.$ exchangeable $\left.\mathrm{NH}\right), 9.88(\mathrm{~s}, 1 \mathrm{H}, \mathrm{CH}$, azomethine ), 6.60-7.49 (m, 6H, Ar-H), $6.08(\mathrm{~s}, 1 \mathrm{H}$, isoxazole) $3.74\left(\mathrm{~s}, 3 \mathrm{H}, \mathrm{OCH}_{3}\right), 3.85\left(\mathrm{~s}, 6 \mathrm{H}, \mathrm{OCH}_{3}\right), 2.28\left(\mathrm{~s}, 3 \mathrm{H}, \mathrm{CH}_{3}\right.$ methyl isoxazole). Anal. calcd. for $\mathrm{C}_{20} \mathrm{H}_{21} \mathrm{O}_{6} \mathrm{~N}_{3} \mathrm{~S}$ : C, 55.67; $\mathrm{H}, 4.91$; N 9.74. Found: C, 54.20; H, 3.77; N, 9.10\%. UV/Vis (DMF, $\lambda_{\max }$, $\mathrm{nm}): 213,292,344$.

\subsection{Synthesis of Schiff base complexes}

Schiff base compounds (0.02 mol) were reacted as ligands with $(0.01 \mathrm{~mol})$ titanium tetrachloride in refluxing ethanol for 24 hrs under nitrogen to give Schiff dibase complexes. The precipitates were crystallized from ethanol (Scheme 1 and 2).

4-(3,4-Dimethoxybenzylideneamino)-N-(5-methylisoxazol-3yl)benzene sulfonamide titanium complex (2): Color: Reddish brown. Yield: 50\%. M.p.: 232-233 ${ }^{\circ} \mathrm{C}$. FT-IR (KBr, v, cm-1): 3432 $(\mathrm{NH}), 1652(\mathrm{C}=\mathrm{N}), 1622$ (C=N ring), 1594 (C=C). ${ }^{1} \mathrm{H}$ NMR (300 MHz, DMSO- $\left.d_{6}, \delta, \mathrm{ppm}\right): 10.94\left(\mathrm{~s}, 2 \mathrm{H}, \mathrm{D}_{2} \mathrm{O}\right.$ exchangeable $\mathrm{NH}$ ), $9.84(\mathrm{~s}, 2 \mathrm{H}, \mathrm{CH}$, azomethine), 6.57-7.58 (m, 14H, Ar-H), 6.08 (s, $2 \mathrm{H}$, isoxazole), $3.82\left(\mathrm{~s}, 6 \mathrm{H}, \mathrm{OCH}_{3}\right), 3.86\left(\mathrm{~s}, 6 \mathrm{H}, \mathrm{OCH}_{3}\right), 2.27(\mathrm{~s}$, $6 \mathrm{H}, \mathrm{CH}_{3}$ methyl isoxazole). Anal. calcd. for $\mathrm{C}_{38} \mathrm{H}_{38} \mathrm{O}_{10} \mathrm{~N}_{6} \mathrm{~S}_{2} \mathrm{TiCl}_{4}: \mathrm{C}$, 45.98; H, 3.86; N, 8.47. Found: C, 45.20; H, 3.90; N, 8.20\%. UV/Vis (DMF, $\left.\lambda_{\max }, \mathrm{nm}\right): 215,281,363,414 . \Lambda_{\mathrm{m}}\left({\mathrm{S} . \mathrm{cm}^{2}}^{2} \cdot \mathrm{mol}^{-1}\right)$ : 42.

N-(5-Nethylisoxazol-3-yl)-4-(3,4,5-trimethoxybenzylidene amino)benzene sulfonamide titanium complex (4): Color: Dark yellow. Yield: 32\%. M.p.: $169-171{ }^{\circ} \mathrm{C}$. FT-IR (KBr, v, cm-1): 3438 $(\mathrm{NH}), 1650(\mathrm{C}=\mathrm{N}), 1623\left(\mathrm{C}=\mathrm{N}\right.$ ring), $1583(\mathrm{C}=\mathrm{C}) .{ }^{1} \mathrm{H}$ NMR (300 MHz, DMSO- $\left.d_{6}, \delta, p p m\right): 11.05\left(\mathrm{~s}, 2 \mathrm{H}, \mathrm{D}_{2} \mathrm{O}\right.$ exchangeable $\mathrm{NH}$ ) 9.83 (s, 2H, CH, azomethine), 6.80-7.59 (m, 12H, Ar-H), 6.09 (s, $2 \mathrm{H}$, isoxazole), $3.82\left(\mathrm{~s}, 6 \mathrm{H}, \mathrm{OCH}_{3}\right), 3.87\left(\mathrm{~s}, 12 \mathrm{H}, \mathrm{OCH}_{3}\right), 2.27(\mathrm{~s}$ $6 \mathrm{H}, \mathrm{CH}_{3}$ methyl isoxazole). Anal. calcd. for $\mathrm{C}_{40} \mathrm{H}_{42} \mathrm{O}_{12} \mathrm{~N}_{6} \mathrm{~S}_{2} \mathrm{TiCl}_{4}$ : $\mathrm{C}$, 45.64; H, 4.02; N, 7.98. Found: C, 45.86; H, 3.40; N, 7.78\%.

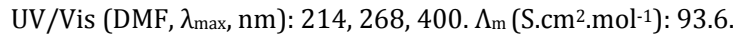

\subsection{Gel electrophoresis}

The DNA cleavage experiment was conducted using CTDNA by gel electrophoresis with the ligand and metal complex in the absence and presence of $\mathrm{H}_{2} \mathrm{O}_{2}$ as an oxidant. 
<smiles>COc1cc(C=O)cc(OC)c1OC</smiles><smiles></smiles><smiles>COc1cc(/C=N/c2ccc(S(=O)(=O)Nc3cc(C)on3)cc2)cc(OC)c1OC</smiles>

(3)
The reaction mixture was incubated before electrophoresis experiment at $37{ }^{\circ} \mathrm{C}$ for $2 \mathrm{~h}$ as follows: Calf thymus DNA, CTDNA $30 \mu \mathrm{M}, 50 \mu \mathrm{M}$, each complex and $500 \mu \mathrm{M} \mathrm{H} \mathrm{H}_{2} \mathrm{O}_{2}$ in $50 \mathrm{mM}$ Tris- $\mathrm{HCl}$ buffer $(\mathrm{pH}=7.1)$. The samples were electrophoresed for $2 \mathrm{~h}$ at $50 \mathrm{~V}$ on $1 \%$ agarose gel using tris-acetic acid-EDTA buffer at $\mathrm{pH}=8.3$. After electrophoresis, the gel was stained using $3 \mu \mathrm{L}$ ethidium bromide (EB) and photographed under UV light using a digital camera.

\subsection{Cytotoxicity}

The cytotoxic activity of the compounds was evaluated in 96-well flat-bottomed microplates by using the standard MTT (3-[4,5-dimethylthiazole-2-yl]-2,5-diphenyl-tetrazolium bromide) colorimetric assay [36]. For this purpose, PC-3 cells (Prostate cancer) and Hela cells were cultured in Dulbecco's Modified Eagle's Medium, and Minimal Essential Medium (MEM), supplemented with $5 \%$ of fetal bovine serum (FBS), $100 \mathrm{IU} / \mathrm{mL}$ of penicillin and $100 \mu \mathrm{g} / \mathrm{mL}$ of streptomycin in 25 $\mathrm{cm}^{3}$ flask, and kept in $5 \% \mathrm{CO}_{2}$ incubator at $37^{\circ} \mathrm{C}$. Exponentially growing cells were harvested, counted with haemocytometer and diluted with a particular medium. Cell culture with the concentration of $1 \times 10^{5}$ cells $/ \mathrm{mL}$ was prepared and introduced (100 $\mu \mathrm{L} /$ well) into 96-well plates. After overnight incubation, medium was removed and $200 \mu \mathrm{L}$ of fresh medium was added with different concentrations of compounds $(1,10$ and 100 $\mu \mathrm{M})$. After $48 \mathrm{~h}, 50 \mu \mathrm{L}$ MTT ( $2 \mathrm{mg} / \mathrm{mL}$ ) was added to each well and incubated further for 4 hours. Subsequently, $100 \mu \mathrm{L}$ of DMSO was added to each well. The extent of MTT reduction to formazan within cells was calculated by measuring the absorbance at $570 \mathrm{~nm}$, using a micro plate reader (Spectra Max plus, Molecular Devices, CA, USA). The cytotoxicity was recorded as concentration causing $50 \%$ growth inhibition ( $\left.\mathrm{IC}_{50}\right)$.

\section{Result and discussion}

\subsection{Synthesis and characterization}

Schiff base ligand was prepared by reaction of sulfamethoxazole with 3,4-dimethoxybenzaldehyde or 3,4,5trimethoxybenzaldehyde in refluxing solvent. Schiff base ligand (0.02 mole) was reacted with $\mathrm{TiCl}_{4}(0.01$ mole) to give Schiff dibase complexes (Scheme 1 and 2).

\subsection{Conductance measurements}

All Ti complexes ( 2 and $\mathbf{4}$ ) are electrolytes as shown by their molar conductivity $\left(\Lambda_{\mathrm{m}}\right)$ measurements in DMF, which are

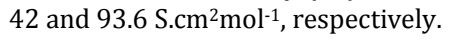

\subsection{IR spectra}

The assigned absorption bands are consistent with the suggested structures. The aromatic $\mathrm{C}=\mathrm{C}$ vibrations were observed in the range 1576-1596 $\mathrm{cm}^{-1}$; the azomethane band is seen at $1650-1656 \mathrm{~cm}^{-1}$; NH single bond of sulfamethoxazaole at $3430-3438 \mathrm{~cm}^{-1}$ [37] and $\mathrm{C}=\mathrm{N}$ oxazole ring at 1619-1623 $\mathrm{cm}^{-1}[38]$.

\section{4. ${ }^{1}$ H NMR study of Schiff base}

1H NMR spectrum of the Schiff base (1), 4-(3,4-dimethoxy benzylideneamino)- $N$-(5-methylisoxazol-3-yl)benzene sulfonamide, showed NH proton of sulfonamide at $10.99 \mathrm{ppm}(\mathrm{s}, 1 \mathrm{H}$, $\mathrm{D}_{2} \mathrm{O}$ exchangeable), $\mathrm{CH}_{3}$ of methyl isoxazole at $2.29 \mathrm{ppm}(\mathrm{s}, 3 \mathrm{H})$, azomethine proton noted at $9.79 \mathrm{ppm}(\mathrm{m}, 1 \mathrm{H})$. The multiple signals around 6.59-7.47 ppm $(\mathrm{m}, 7 \mathrm{H})$ are ascribed to aromatic protons. The signal observed at $6.06 \mathrm{ppm}(\mathrm{s}, 1 \mathrm{H})$ is due to isoxazole proton. $\mathrm{OCH}_{3}$ protons showed up at $3.72 \mathrm{ppm}(\mathrm{s}, 3 \mathrm{H})$ and at $3.84 \mathrm{ppm}(\mathrm{s}, 3 \mathrm{H})$.

${ }^{1} \mathrm{H}$ NMR spectrum of the Schiff base (3), $N$-(5-methyl isoxazol-3-yl)-4-(3,4,5-trimethoxybenzylideneamino) benzene sulfonamide, showed $\mathrm{NH}$ proton of sulfonamide at $10.95 \mathrm{ppm}$ (s, $1 \mathrm{H}, \mathrm{D}_{2} \mathrm{O}$ exchangeable), $\mathrm{CH}_{3}$ of methyl isoxazole at $2.28 \mathrm{ppm}$ $(\mathrm{s}, 3 \mathrm{H})$ and azomethine proton noted at $9.88 \mathrm{ppm}(\mathrm{s}, 1 \mathrm{H})$. The multiple signals around $6.60-7.49 \mathrm{ppm}(\mathrm{m}, 6 \mathrm{H})$ are ascribed to aromatic protons. Signal observed at $6.08 \mathrm{ppm}(\mathrm{s}, 1 \mathrm{H})$ is due to 
isoxazole proton. $\mathrm{OCH}_{3}$ protons were noted at $3.74 \mathrm{ppm}(\mathrm{s}, 3 \mathrm{H})$ and at $3.85 \mathrm{ppm}(\mathrm{s}, 6 \mathrm{H})$.

\section{5. ${ }^{1}$ H NMR study of the complexes}

In the ${ }^{1} \mathrm{H}$ NMR spectra of the complexes (2 and 4$)$ an electron density shift from the ligand to the metal complex was observed. The signals of azomethine protons appeared at 9.84 and $9.83 \mathrm{ppm}$ in the compound 2 and 4, respectively, as compared to $9.79 \mathrm{ppm}$ and $9.88 \mathrm{ppm}$ in the Schiff base, confirming coordination through the azomethine nitrogen atom of the ligand [39].

\subsection{Electronic spectra}

The main electronic absorptions are shown in Figure 1. UVVis spectra of the ligands and their complexes were measured in the range $200-800 \mathrm{~nm}$. The lower wavelength in the range $200-400 \mathrm{~nm}$ is specific for the electronic intra-ligand transitions. The spectra of complexes generally show the characteristic band of the free ligands with some changes both in wavelengths $\left(\lambda_{\max }\right)$ and intensity, together with appearances of new bands at longer wavelengths. The spectra of the ligands and their complexes exhibit bands in the regions of 213-215, 268-292 and 343-414 $\mathrm{nm}$, which may be attributed to the transitions of $\sigma \rightarrow \sigma^{*}, \pi \rightarrow \pi^{*}$ and $n \rightarrow \pi^{*}$, respectively.

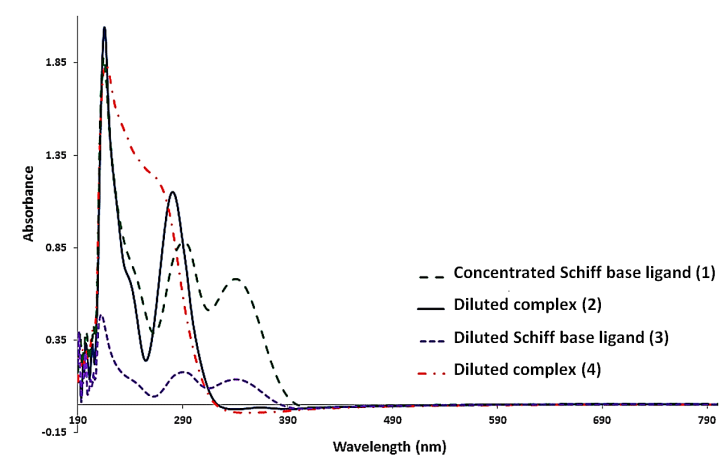

Figure 1. UV-Vis spectra of the two ligands and their metal complexes.

\subsection{DNA cleavage studies}

The cleavage efficiency of the complexes compared to that of control is due to their efficient DNA-binding ability. The metal complexes were able to convert super coiled DNA into open circular DNA. The proposed general oxidative mechanisms and account of DNA cleavage is by hydroxyl radicals via abstraction of a hydrogen atom from sugar units that predict the release of specific residues arising from transformed sugars, depending on the position from which the hydrogen atom is removed [40]. Free radical scavengers inhibit cleavage. This implies that hydroxyl radical or peroxy derivatives mediate the cleavage reaction. The reaction is modulated by metal complexes bound hydroxyl radical or a peroxo species generated from the co-reactant $\mathrm{H}_{2} \mathrm{O}_{2}$.

In the present study, CT-DNA gel electrophoresis experiment was conducted at $35{ }^{\circ} \mathrm{C}$ using our synthesized complexes in the presence of $\mathrm{H}_{2} \mathrm{O}_{2}$ as an oxidant. As can be seen from the results illustrated in Figure 2 and 3, at very low concentrations, all ligands and their complexes exhibited nuclease activity in the presence of $\mathrm{H}_{2} \mathrm{O}_{2}$. Control-1 experiment, using DNA alone (line 1) did not show any significant cleavage of CT-DNA even on a longer exposure time. Control-2, using $\mathrm{DNA}+\mathrm{H}_{2} \mathrm{O}_{2}$ (line 2) did not show any significant cleavage of CTDNA. From the observed results, it can be concluded that all ligands (lines 3 and 5) and their complexes (lines 4 and 6) showed complete cleavage of CT-DNA.

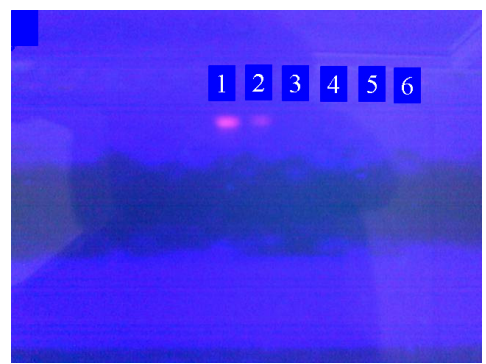

Figure 2. DNA with hydrogen peroxide and chemical compounds: 1-DNA alone; 2-DNA $+\mathrm{H}_{2} \mathrm{O}_{2} ; 3$-DNA $+\mathrm{H}_{2} \mathrm{O}_{2}+$ Compound $1 ;$ 4-DNA $+\mathrm{H}_{2} \mathrm{O}_{2}+$ Compound 2; 5-DNA + $\mathrm{H}_{2} \mathrm{O}_{2}+$ Compound 3; 6-DNA $+\mathrm{H}_{2} \mathrm{O}_{2}+$ Compound 4.

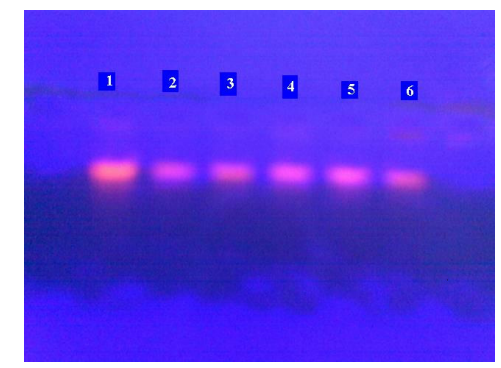

Figure 3. DNA without hydrogen peroxide: 1-DNA alone; 2 -DNA + solvent (DMSO); 3-DNA + Compound 1; 4-DNA+ Compound 2; 5-DNA + Compound 3; 6-DNA + Compound 4.

\subsection{Anti-cancer activity}

The results of the in vitro anticancer activity of the tested compounds 1-4 were evaluated for cytotoxicity against PC3 cells (Prostate cancer) and Hela cells of humans in comparison with doxorubicin as a positive control. All the tested compounds showed a limited cytotoxic activity. Table 1 represents the cytotoxic activity of the tested compounds.

Table 1. Cytotoxic activity against Hela cells and PC3 cells.

\begin{tabular}{lll}
\hline Compound & PC3 & Hela \\
\cline { 2 - 3 } & IC $_{50} \pm$ SD $(\boldsymbol{\mu M})$ & IC $_{\mathbf{5 0}} \pm$ SD $(\boldsymbol{\mu M})$ \\
\hline 1 & $35.67 \pm 1.7$ & $37.66 \pm 0.2$ \\
2 & $32.6 \pm 0.5$ & $36.75 \pm 1.0$ \\
3 & $50.76 \pm 0.2$ & $54.98 \pm 1.1$ \\
4 & $>100$ & $>100$ \\
Doxorubicin (as control) & $0.912 \pm 0.120$ & $3.10 \pm 0.2$ \\
\hline
\end{tabular}

\section{Conclusion}

The present work describes the synthesis, characterization and in vitro anticancer evaluation of two sulfonamide derivatives and their complexes. With regard to anticancer activity we expected the titanium complexes to give excellent cytotoxic activity, however all tested compounds showed limited cytotoxic activity and complete cleavage of CT-DNA.

\section{References}

[1]. Naik, A. D.; Annigeri; Gangadharmath, S. M. U. B.; Ravankar , V. K.; Mahale, V. B.; Reddv, V. K. Ind. J. Chem. A 2002, 41(10), 2046-2053.

[2]. Sen, A. K.; Singh G.; Singh, K.; Handa, R. N.; Dubey, S. N.; Squattirito,P. J. Pro. Ind. Acad. Sci. 1998, 110, 75-81.

[3]. Sen, A. K.; Singh, G.; Singh, K.; Noren, R. K.; Handa, R. N.; Dubey, S. N. Ind. J. Chem. 1997, 36A, 891-894.

[4]. Drabent, K.; Bialoska, A.; Ciunik, Z. Inorg. Chem. Commun. 2004, 7(2), 224-227. 
[5]. Klingele, M. H.; Brooker, S.; Coord. Chem. Rev. 2003, 241 (1-2), 119132.

[6]. Arion, V. B.; Reisner, E.; Jokupec, M. A.; Keppler, B. K.; Kukushkin, V. Y.; Pombeiro, A. J. L. Inorg. Chem. 2003, 42(19), 6024-6031.

[7]. Mashaly, M.; Boyoumi, H. A.; Taha, A. Chem. Papers 1999, 53(5), $299-$ 308.

[8]. Kabeer, A. S.; Baseer, M. A.; Mote, N. A. Asian. J. Chem. 2001, 13(2), 496-500.

[9]. El-Masry, A. H.; Fahmy, H. H.; Abdelwahed, S. H. A. Molecules 2000, 5, 1429-1438.

[10]. More, P. G.; Bhalvankar, R. B.; Patter, S. C. J. Ind. Chem. Soc. 2001, 78(9), 474-475.

[11]. Pandeya, S. N.; Sriram, D.; Nath, G.; Clereq, E. D. Il Farmaco 1999, 54, 624-628.

[12]. Singh, W. M.; Dash, B. C. Pesticide. 1988, 22(11), 33-37.

[13]. Desai, S. B.; Desai, P. B.; Desai, K. R. Heterocycl. Commun. 2001, 7(1), 83-90.

[14]. Pathak, P.; Jolly, V. S.; Sharma, K. P. Orient J. Chem. 2000, 16(1), 161162.

[15]. Samadhiya, S.; Halve, A. Orient J. Chem. 1988 17(1), 33-37.

[16]. Ferrari, M. B.; Capacchi, S.; Pelosi, G.; Reffo, G.; Tarasconi, P.; Albertini, R.; Pinelli , S.; Lunghi ; P. Inorg. Chim. Acta. 1999, 286, 134-141.

[17]. Canpolat, E.; Kaya, M. J. Coord. Chem. 2004, 57, 1217-1223.

[18]. Yildiz, M.; Dulger, B.; Koyuncu, S. Y.; Yapici, B. M. J. Indian Chem. Soc. 2004, 81, 7-12.

[19]. Wong, E.; Giandomenico, C. M. Chem. Rev. 1999, 99, 2451-2466.

[20]. Clarke, M. J.; Zhu, F.; Frasca, D. R. Chem. Rev. 1999, 99, 2511-2533.

[21]. Kratz, F.; Schutte, M. T. Cancer J. 1998, 11, 176-182.

[22]. Kopf-Maier, P. Eur. J. Clin Pharmacol. 1994, 47, 1-16.

[23]. Kopf-Maier, P.; Kopf, H. Chem. Rev. 1987, 87, 1137-1152.

[24]. Melendez, E. Crit. Rev. Oncol. Hemat. 2002, 42, 309-315.

[25]. Caruso, F.; Rossi, M.; Pettinari, C. Expert. Opin. Ther. Pat. 2001, 11, 969-979.

[26]. Kopf-Maier, P.; Kopf, H. Struct. Bonding. 1988, 70, 103-185.

[27]. Kelter, G.; Sweeney, N. J.; Strohfeldt, K.; Fiebig, H. H.; Take, M. Anticancer Drugs. 2005, 16, 1091-1098.

[28]. Christodoulou, C. V.; Elipoulos, A. G.; Young, L. S.; Hodgkins, L.; Ferry, D. R.; Kerr, D. J. British. J. Cancer. 1998, 77, 2088-2097.

[29]. Keppler, B. K.; Friesen, C.; Moritz, H. G.; Vongerichten; Vogel, H. E. , Struct. Bonding. 1991, 78, 97-127.

[30]. Caruso, F.; Rossi, M.; Tanski, J.; Sartori, R.; Sariego, R.; Moya, S.; Diez, S.; Navarrete, E.; Cingolani, A.; Marchetti, F.; Pettinari, C. J. Med. Chem. 2000, 43, 3665-3670.

[31]. Majumder, A.; Rosair, G. M.; Mallick, A.; Chattopadhyay, N.; Mitra, S. Polyhedron 2006, 25, 1753-1762.

[32]. Singh, K.; Barwa, M. S.; Tyagi, P. Eur. J. Med. Chem. 2006, 41(1), 147153.

[33]. Korfel, A.; Scheulen, M. E.; Schmoll, H. J.; Grundel, O.; Harstrick, A.; Knoche, M.; Fels, M.; Skorzec, M.; Bach, F.; Baumgart, J.; Sab , G.; Seeber, S.; Thiel, E.; Berdel, W. E. Clin. Cancer Res. 1998, 4, 2701-2708.

[34]. Lummen, G.; Sperling, H.; Luboldt, H.; Otto, T.; Rubben, H. Cancer Chemother. Pharmacol. 1998, 42, 415-417.

[35]. El-Shekeil, A.; Obeid, A. O.; Al-Aghbari, S. Eur. J. Chem. 2012, 3(3), 356358.

[36]. Irob, O. N.; Moo-Young, M.; Anderson, W. A. Intl. J. Pharmacogn. 1996, 34, 87-90.

[37]. Mosmann, T. J. Iimmunol. Methods 1983, 65, 55-63.

[38]. Silverstien, M.; Bassler, G.; Morril, C., Spectrometric Identification of Organic Compounds, $4^{\text {th }}$ edn., p. 133, John Wiley \& Sons, New York, 1981.

[39]. Katritzky, A. R.; Pozharskii, A. F. Handbook of Heterocyclic Chemistry, $2^{\text {nd }}$ edn, p. 117, Pergamon, UK, 2000.

[40]. Prasad, K. S; Kumar, L. S; Parasad, M.; Revanasiddappa, H. D. Bioinorg. Chem. Appl. 2010, Article ID: 854514, 1. 